\begin{tabular}{|l|l|c|c|}
\hline Eiszeitalter u. Gegenwart & 38 & $\begin{array}{c}94-105 \\
3 \text { fig., } 1 \text { tab. }\end{array}$ & Hannover 1988 \\
\hline
\end{tabular}

\title{
A New Chronostratigraphy of the Late Weichselian Loess Units in Middle Europe based on Thermoluminescence Dating
}

\author{
Etienne H. Juvigné \& AnN G. Wintle *)
}

\begin{abstract}
Weichselian, interglacial environment, marker bed, paleosol, tuff, loess,
$\mathrm{U}, \mathrm{Th}, \mathrm{K}$, chemical analysis, thermoluminescence dating, C 14 dating, chronostratigraphy
\end{abstract}

Belgium, West Germany

\begin{abstract}
The ages of tephra layers, soils and loess bodies of the late Weichsel are discussed using a consistent set of twentythree thermoluminescence (TL) ages and two radiocarbon ages. Two other radiocarbon ages are rejected since they are inconsistent with the other twentyfive dates. A new chronostratigraphy of the late weichselian loess units is introduced. It is in agreement with the interpretation of the continuous pollen record of Les Echets/France and the loess sequence shows no evidence of interstadial climate. The late weichselian loess was deposited in a period of less than ten thousand years.
\end{abstract}

[Eine neue Chronostratigraphie der spät-weichselzeitlichen Lößkörper Mitteleuropas aufgrund von Thermoluminescenz-Datierungen]

Kurzfassung: Diese Untersuchung wurde innerhalb des Verbreitungsgebietes des Eltviller Tuffs (Abb. 1) durchgeführt, wobei die Tephralage sowie ein fossiler Boden (E4Naßboden + Innerwürmboden II + Nagelbeek-Kryoturbationszungenhorizont $+\mathrm{J} 3 \mathrm{~d}$-Boden) als Leithorizonte benutzt werden. In der Abbildung 3 sind die bisherige Chronostratigraphie (untere Skala) sowie die neue Chronostratigraphie (obere Skala) oberer Weichsel-Lösse angegeben. Die durch Thermoluminescenz neu datierten Proben (Rocourt und Lixhe/Belgien, Ringen/B.R.D.) sind in der Abbildung lokalisiert. Die neuen Ergebnisse sowie frühere Thermoluminescenz- und $14 \mathrm{C}$-Altersbestimmungen wurden in der Abbildung 3 dargestellt. So können Tephralagen, fossile Böden sowie Lößkörper aufgrund einer hangenden Folge von 23 Thermoluminescenz- sowie zwei 14C-Altersbestimmungen festgestellt werden. Die lithostratigraphischen Angaben der hochglazialen Lösse weisen darauf hin, daß keine deutliche Erwärmung zwischen dem Ende des mittel-weichsel-

*) Addresses of the authors: E. H. Juvigne, Université de Liège, Laboratoire de Géomorphologie et de Géologie du Quaternaire, Place du XX Août, 7, 4000 Liège, Belgium. A. G. Wintle, The Godwin Laboratory, University of Cambridge, Free School Lane, Cambridge CB 23 RS, U. K now at Geography Department, Royal Holloway and Bedford New College, Egham, Surrey TW 20 OEX. U. K. zeitlichen Interstadials (28.000 J.B.P.) und 15.000 J.B.P. stattgefunden hat und daher müssen Laugerie- sowie Lascaux-Interstadiale höchstens als Oszillation betrachtet werden. Die erste deutliche Erwärmung nach dem mittelweichselzeitlichen Interstadial hat zwischen ca. 15.000 und 14.000 J.B.P. stattgefunden. Diese wird als „Nagelbeek Oszillation" bezeichnet. Nach der bisherigen Chronostratigraphie muß diese warme Oszillation in die Mitte der ältesten Tundrenzeit eingestuft werden. Dabei wird die kalte Oszillation verkürzt, da ihr unterster Teil an das ausklingende Weichsel-Hochglazial angeschlossen werden kann. Die obigen Ergebnisse stimmen mit der Interpretation der äquivalenten Zeitabschnitte des Pollendiagrammes von Les Echets/Frankreich überein. Zwischen 14.000 J.B.P. und

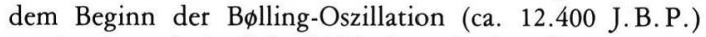
wurde eine relativ dicke Lößdecke mit einer Rate von ca. $2 \mathrm{~mm} / \mathrm{Jahr}$ abgelagert. Aufgrund der neuen Altersbestimmungen können auch der Eltviller Tuff auf ca. 16.200 J.B.P. und der Rambacher/Wallertheimer Tuff auf ca. 19.400 J.B.P. datiert werden.

\section{Introduction}

We have investigated the late weichselian loess sections of middle Europe which are located within the lobe of the Eltville tephra (Fig. 1). In the last twenty years several authors have commented on the late weichselian loess stratigraphy using sections in which the Eltville tephra is present. Their conclusions are shown in figure 2 . In this area two stratigraphic units are of the greatest importance because they are present in each of the sections. These are the Eltville tephra layer and the soil named "E4-Naßboden", "J3d grauer Boden", "Innerwürmboden III", or "Horizon à langues de Nagelbeek" (Fig. 2). There is general agreement about the correlation of the Eltville tephra and the individual soils as represented in figure 2. In the following text, this soil is simply named "tongued horizon" referring to the typical tongues at its base. It should also be emphasized that 


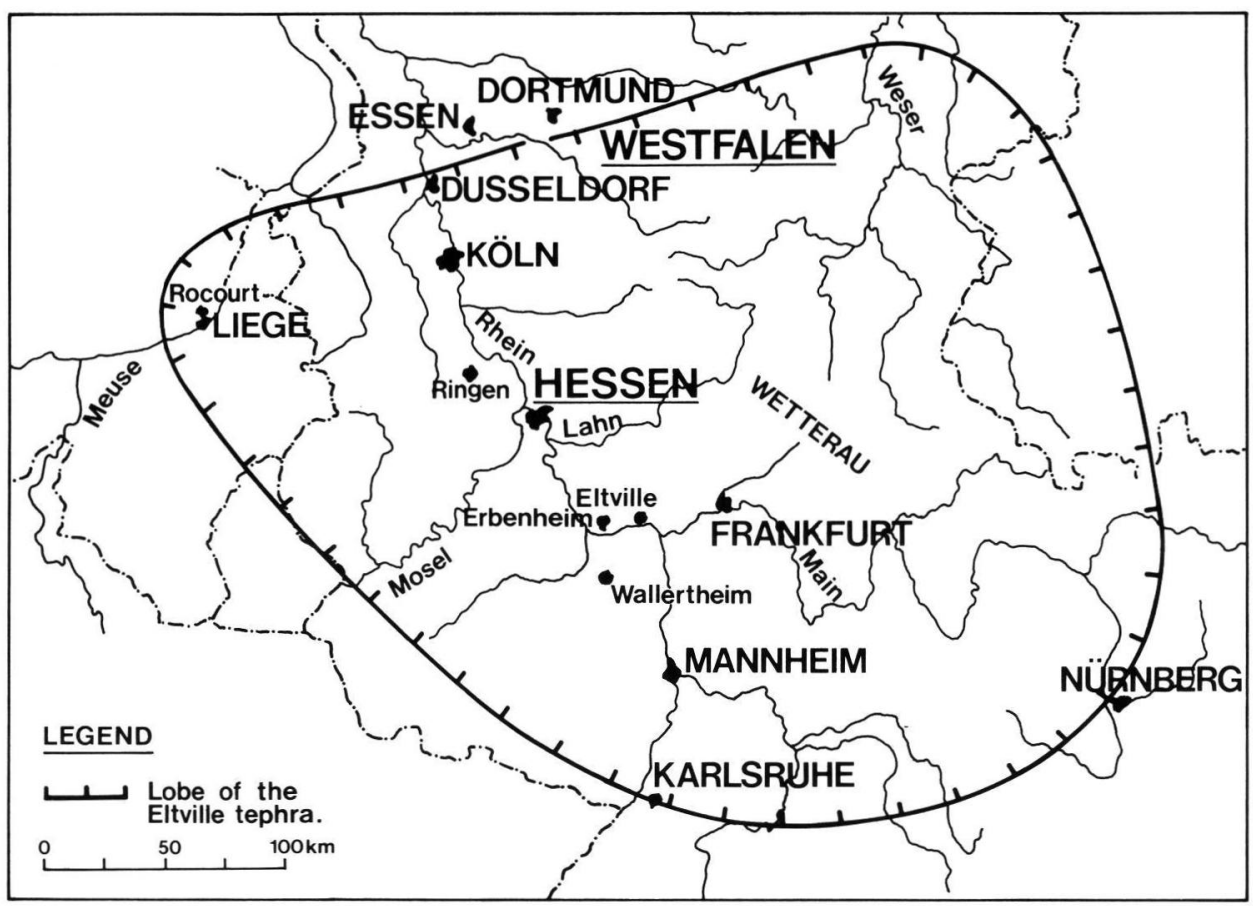

Fig. 1: Lobe of the Eltville tephra (according to MEIJ et al. 1983) with main localities cited in text.

this tongued horizon is penetrated by large ice wedges in the overlying loess sheet.

The age of the late weichselian loess units will be discussed with particular attention being given to the two stratigraphic markers. Absolute ages using different material from the late weichselian loesses are contradictory but indicate an age around 20,000 years B. P. for the sequence from the "E2-Naßboden" (E2-wet soil) up to the tongued horizon.

\section{Stratigraphic markers in the sequences}

\subsection{The tongued horizon}

The term "horizon à langues/à franges" (tongued/fringed horizon) was introduced by GULLENTOPS (1954) who pointed out its occurrence in all the profiles that he described in eastern middle Belgium. The tongued horizon was later found systematically in loess profiles of northern France (LAUTRIDOU 1968; PAEPE \& SOMME 1970), western middle Belgium (HAESAERTS 1974; HAESAERTS et al. 1981), Dutch Limbourg (MEIJS et al. 1983) and southern lower Saxony to northern Hesse/F.R.G. (RoHDEnBuRg 1966). The tongued horizon does not occur as such in the loess profiles of the middle and lower Rhine and its lower adja- cent valleys, but it is present without tongues as the "Innerwürmboden III" and "E2-Naßboden" (Fig. 2). Hence the tongued horizon is the most developed and widespread morphostratigraphical horizon (PAEPE \& Somme in HaESAERTS et al. 1981) of the loess stratigraphy of middle Europe. Its humic content was demonstrated by GULLENTOPS (in HAESAERTS et al. 1981) and its temperate pollen suite was described by BASTIN (1971). It was given the name "horizon à langues de Nagelbeek" (Nagelbeek tongued horizon) by HAESAERTS et al. (1981).

\subsection{The "Kesselt Soil"}

Since the well-known term "Kesselt Soil" has been widely used in relation to the loess stratigraphy of middle Europe for the last 30 years, it must be explained why it is not considered as the most important soil, even though it is present in the sequence under consideration (Fig. 2, $\log \mathrm{J}$ ). The term was introduced by GULLENTOPS (1954) for the unit which immediately underlies the tongued horizon but with a discontinuity in between. GULLENTOPS attributed no climatic significance to the tongued horizon but introduced the Kesselt Soil as the only interstadial soil of the Weichsel. Later, the term Kesselt soil was applied to the tongued horizon and correlated with the Stillfried 


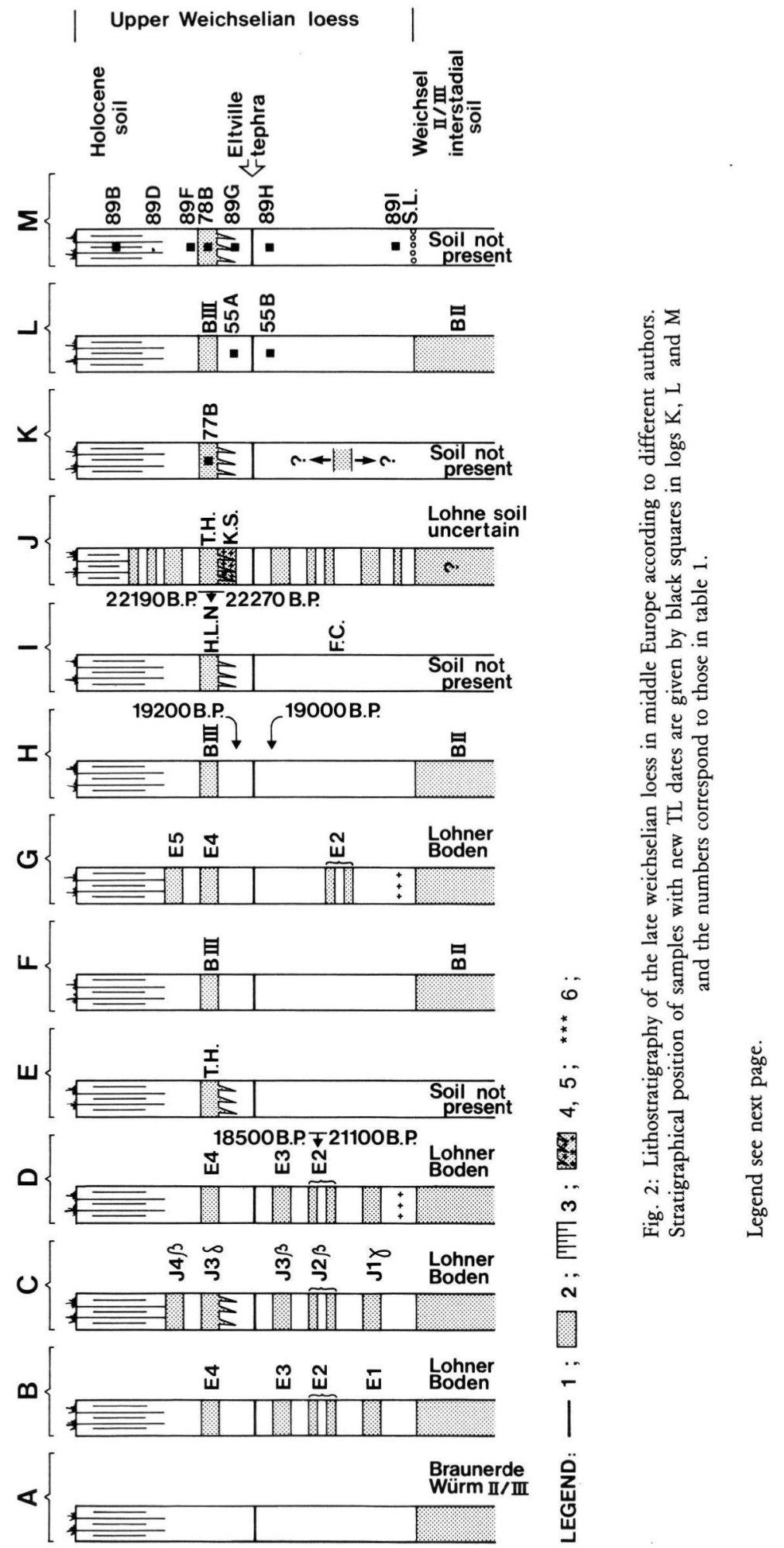


Legend:

1. Eltville tephra layer; 2. Paleosol: the connotation and names fit with those used by each author; 3 . Holocene soil; 4. Tongued horizon; 5. Kesselt Soil; 6. Rambach / Wallertheim tephra layer.

A: According to ScHÖNHALS (1951) in Lahn and Main valleys. The tephra layer is simply cited as dark grey layer of volcanic material; SCHÖNHALS (1959) used the name "Kärlicher Tuff" for the tephra layer.

B: According to SCHÖNHALS et al. (1964) in Rhine-Main area. Four "Naßböden" (wet soils) were identified at Erbenheim (F.R.G.) and are labelled E1, E2, E3, and E4. The tephra is still named Kärlicher Tuff.

C: According to RohDenburg \& MeYer (1966) and RoHDENBURG (1966) in southern lower Saxony and northern Hesse. Five "graue Böden" (grey soils) were identified and are labelled J1 g, J2 b, J3 b, J3 d, and J4 b, the most important of which is $\mathrm{J} 3 \mathrm{~d}$ which is reported as the most developed soil within the late weichselian loess. It is tongued at the base.

D: According to Semmel (1967) in Hesse. The term "Eltviller Tuff" was introduced instead of Kärlicher Tuff.

The occurrence of another tephra layer at the base of the late weichselian loess was pointed out and named "Rambacher Tuff". Shells from the E2-Naßboden were dated at 18,500 \pm 950 years B. P. (Hv-1296) and 21,100 $\pm 1,400$ years B. P. (Hv-1297) (SEmmel 1974). Andres (1969) in Rhine Hesse area and Bibus (1973) in the Wetterau (F. R. G.) have a similar stratigraphy.

E: According to Rohdenburg \& Semmel (1971) who discovered the Eltville tephra at Rocourt (Belgium). Since Belgian stratigraphic terms were misused (see in text) they were corrected to avoid further confusion. T. H. means tongued horizon. This stratigraphy was confirmed by Juvigné \& SEMMEL (1981).

F: According to LOHR \& BRUNNACKER (1974) in the lower Rhine. BIII means "Innerwürmboden III" (wurmian interstadial soil III). Correlation of this soil with the "Laugerie-Lascaux Interstadial" was proposed. BII is the "Innerwürmboden II".

G: According to BiBus \& SEMmel (1977) in the middle Rhine. BiBus (1980) obtained a similar stratigraphy for the lower middle Rhine.

H: According to BRUNNACKer et al. (1978) at Lommersum (lower Rhine Bay) and BrUNNACKER \& TILLMANS (1978) at Wallertheim (Hesse). TL ages are reported on the log according to WINTLE \& BRUNNACKER (1982):

$19,200 \pm 1,900$ years B.P. (QTL 32 A) and 19,000 $\pm 1,900$ years B.P. (QTL 32 B). Since BrunNaCKer \& Tillmans

(op. cit.) placed the "Wallertheimer Tuff" below the "Lohne Soil", the relevant sequence is not represented in the log. For connotations BII und BIII see log F.

I: According to Haesaerts et al. (1981) in Dutch and Belgian Limbourg. The "Horizon à langues de Nagelbeek" (H.L.N.) was introduced to designate the tongued horizon. Radiocarbon dates on humus were reported by GULLENTOPS (1981): 22,190 \pm 130 years B. P. (GrN-10328) and 22,270 2380 years B. P. (Lv-1172).

J: According to Mejs et al. (1983) in Dutch and Belgian Limbourg. T. H. means tongued horizon.

K.S. means Kesselt Soil. This nomenclature will be discussed in text.

K: Loess profile at Lixhe (Belgium) according to GuLLENTOPs (1980).

There is nothing to allow the correlation of the Lower Naßboden at Lixhe with E1-, E2-, or E3-Naßboden.

L: Loess profile at Ringen (F.R. G.) according to LOHR \& BRUNNACKeR (1974). For connotations BII and BIII see log F.

M: Loess profile at Rocourt, simplified from WintLE (1987a). S. L. means stony layer.

B Soil (PAEPE 1966). This confusion was repeated in papers dealing with the late weichselian loess of middle Europe. HAESAERTS (1974) was the first to point out this confusion and he described the "H.H.B.4p.p. Soil" as equivalent to the Stillfried B Soil. In the following text the major temperate phase corresponding to this soil development is simply called "Midweichselian Interstadial".

Commenting on a meeting held to discuss this confusion GULLENTOPS (in HAESAERTS et al. 1981) confirmed his original definitions of both terms (tongued horizon and Kesselt Soil) and proposed the use of "Kesselt B Soil" for the tongued horizon and "Kesselt A Soil" for the Kesselt Soil as originally defined.
Moreover, regardless of the discontinuity separating the tongued horizon and the Kesselt Soil, he indicated that they developed immediately after each other at about 22,000 years B.P. This obviously implied that GULLENTOPS disagreed with the correlation of Kesselt A or Kesselt B with the Midweichselian Interstadial.

MUCHer (in HAESAERTS et al. 1981) pointed out that, according to soil-micromorphological research, the Kesselt Soil (Kesselt A Soil) does not show any sign of soil formation; the relevant horizon is only recognizable from its orange colour. Thus it is inappropriate to try to correlate the Kesselt Soil with any other interstadial horizon or any other soil. 


\subsection{The Eltville tephra layer}

Several authors have commented on the age and distribution of the Eltville tephra (see explanations of figure 2). SEMMEL (1967) thought that it should be younger than 21,100 years B.P. WINTLE \& BRUNNACKER (1982) thought that it was deposited about 19,000 years B.P. On the other hand GULLENTOPS (1981) thought that it should be older than 22,000 years B.P. This contradiction is discussed below with reference to new results.

\section{Sampling}

Samples for thermoluminescence dating were taken at three localities: Rocourt (QTL103A and B and QTL78A and B), Lixhe (QTL77B) and Ringen (QTL55 A and B)) and their stratigraphical position is given in figure 2. Details about a further nine samples from Rocourt (QTL89 B, D, F, G, H and I) have been published elsewhere (WINTLE 1987a) but are shown in figure 2 for completeness.

Tab. 1: Thermoluminescence results and radioactivity data

\begin{tabular}{|c|c|c|c|c|c|c|c|c|c|}
\hline sample & $\begin{array}{l}\text { bulk count } \\
\text { rate }\left(\mathrm{ks}^{-1} \mathrm{~cm}^{-2}\right)\end{array}$ & $\mathrm{U}$ & Th & $\mathrm{S} / \mathrm{U}$ & $\begin{array}{l}\mathrm{K}_{2} \mathrm{O} \\
(\%)\end{array}$ & $\alpha$ & $\begin{array}{l}\text { dose rate } \\
(\mathrm{Gy} / \mathrm{ka})\end{array}$ & $\begin{array}{l}\text { ED } \\
(\mathrm{Gy})\end{array}$ & $\begin{array}{l}\text { TL age } \\
\text { (ka) }\end{array}$ \\
\hline QTL 78B & $0.867 \pm 0.019$ & 3.7 & 12.1 & 1.01 & 1.94 & $0.10 \pm 0.01$ & 4.50 & $68.7 \pm 1.5$ & $15.3 \pm 1.3$ \\
\hline QTL 77 B & $0.676 \pm 0.009$ & 3.4 & 7.5 & 1.03 & 2.00 & $0.10 \pm 0.01$ & 3.72 & $58.9 \pm 2.0$ & $15.8 \pm 1.3$ \\
\hline QTL 55 B & $0.757 \pm 0.013$ & 3.5 & 9.55 & 0.96 & 1.82 & $0.12 \pm 0.01$ & 4.28 & $70.1 \pm 1.1$ & $16.4 \pm 1.4$ \\
\hline QTL103A & $0.831 \pm 0.016$ & 4.3 & 9.0 & 1.12 & 1.83 & $0.12 \pm 0.01$ & 4.58 & $73.0 \pm 3.0$ & $15.9 \pm 1.3$ \\
\hline QTL 78 A & $0.943 \pm 0.019$ & 4.8 & 10.5 & 0.94 & 1.95 & $0.10 \pm 0.02$ & 4.77 & $81.8 \pm 3.5$ & $17.2 \pm 1.7$ \\
\hline QTL 55 A & $0.771 \pm 0.017$ & 4.4 & 7.1 & 0.98 & 1.74 & $0.12 \pm 0.01$ & 4.28 & $68.8 \pm 2.3$ & $16.1 \pm 1.4$ \\
\hline QTL103B & $0.892 \pm 0.017$ & 3.5 & 13.5 & 1.04 & 1.70 & $0.12 \pm 0.01$ & 4.63 & $77.0 \pm 2.0$ & $16.6 \pm 1.3$ \\
\hline
\end{tabular}

Rocourt data (from WINTLE 1987 a)

$\begin{array}{llllllllll}\text { QTL 89B } & 0.716 \pm 0.012 & 3.5 & 8.7 & 1.02 & 2.35 & 0.12 \pm 0.01 & 4.51 & 60.8 \pm 2.4 & 13.5 \pm 1.1 \\ \text { QTL89D } & 0.736 \pm 0.019 & 4.5 & 5.7 & 1.01 & 2.12 & 0.10 \pm 0.01 & 4.18 & 55.3 \pm 1.4 & 13.2 \pm 1.1 \\ \text { QTL89F } & 0.750 \pm 0.017 & 3.8 & 8.5 & 1.15 & 2.24 & 0.12 \pm 0.01 & 4.56 & 61.6 \pm 1.5 & 13.5 \pm 1.1 \\ \text { QTL89G } & 0.866 \pm 0.020 & 4.8 & 8.4 & 1.07 & 1.86 & 0.12 \pm 0.01 & 4.72 & 63.5 \pm 3.5 & 13.5 \pm 1.2 \\ \text { QTL89H } & 0.815 \pm 0.018 & 3.6 & 11.1 & 1.01 & 1.91 & 0.10 \pm 0.01 & 4.30 & 73.4 \pm 0.7 & 17.1 \pm 1.4 \\ \text { QTL89I } & 0.833 \pm 0.017 & 5.2 & 6.8 & 1.08 & 1.74 & 0.13 \pm 0.01 & 4.65 & 115 \pm 3 & 24.8 \pm 2.1\end{array}$

The bulk alpha count is a measure of the alpha activity of the sample and this is used to calculate the fraction of the dose rate from the uranium and thorium decay chains. The $U$ and Th ppm values are obtained from the alpha counting results. The ratio $\mathrm{S} / \mathrm{U}$ is the ratio of the sealed to unsealed alpha count and is a measure of radon emanation. $\alpha$ represents the relative efficiency of alpha particles at producing TL as measured with an Americium-241 source. These data are combined with the potassium content as measured by atomic absorption spectrometry and a small cosmic ray contribution in the calculation of the dose rate. A correction for a water content of $20 \%$ was applied. The TL age is obtained by dividing the ED from the TL measurements by the dose rate. Errors given are $\pm 1 \sigma$. Further information can be obtained from AITKEN (1985). 


\section{Thermoluminescence dating}

The thermoluminescence (TL) properties of minerals such as quartz and feldspars enable sedimentary grains to be dated directly (WINTLE \& HUNTLEY 1982; BERGER 1986). Loess is well suited to application of the TL method since exposure to sunlight during transport prior to deposition removes the earlier TL signal. The TL signal then grows with time as the grains are exposed to radiation from the decay of naturally-occurring radioactive elements within the sediment. A recent review of applications of TL dating to loess and a discussion of the different laboratory procedures has appeared elsewhere (WINTLE $1987 \mathrm{~b}$ ).

Laboratory procedures involve the measurement of the natural TL signal and the TL sensitivity of the sample to laboratory irradiation. Together these are used to calculate the equivalent dose (ED) used in the age equation \# \# TL age (years) $=\frac{\mathrm{ED} \text { (grays) }}{\text { dose rate }(\text { grays } / \text { year })}$

The dose rate is obtained by measurement of the radioactive content of the sediment allowing for appropriate dosimetric considerations. Thick source alpha counting was used to determine the uranium and thorium contents and the ${ }^{40} \mathrm{~K}$ contribution was calculated from the $\mathrm{K}_{2} \mathrm{O}$ content obtained by atomic absorption spectrometry. The TL results presented in table 1 were obtained using the regeneration method of ED determination on fine grain polymineral samples and further experimental details can be found elsewhere (WINTLE 1987a).

Other TL dates that have been used in determining the weighted mean age include those reported for three sediment samples (OxTL 712a, d and g) from Belvedere (near Maastricht, S.E. Netherlands) by HUXTABLE \& AITKEN (1985) and another three (OxTL 704f 1, f2 and f3) which have been obtained at the brickpit site at Biache-Saint-Vaast (Pas-de-Calais) (AITKEN et al. 1986; SOMme 1978). These ages were obtained in Oxford using the regeneration method of ED determination for fine grain polymineral samples. The TL was observed with a UG 11 filter in front of a quartz-windowed EMI9635 photomultiplier tube, thus observing more of the ultraviolet part of the spectrum than the system in Cambridge. No EDs, or other analytical data (apart from the in situ gamma spectrometer determinations) have been published to enable further comparisons; also the ages were calculated using an iterative procedure to include a small correction for long term instability of the TL signal (AITKEN et al. 1986). For direct comparison with the dates obtained in this study the correction has been removed.
Four earlier TL dates (QTL32 A, B, C, and D) on loess from Wallertheim, Germany, published by WINTLE \& BRUNNACKER (1982) have also been included in figure 3 .

\section{Results}

New TL ages are listed in table 1 . These are also given in figure 3 , along with previously reported radiocarbon and TL dates. They were grouped according to the main lithostratigraphical units. Applying the statistical method of LONG \& RIPPETEAU (1974), weighted mean ages were calculated using the data set within each unit in figure 3 . The error term is the standard deviation of the mean. In lithostratigraphic order these are:

- oldest pleniglacial loess of middle Germany: $19,300 \pm 1,400$ years BP ( 3 TL dates)

- shells from E2-Naßboden: 19,320 \pm 786 years B.P. $\left(2{ }^{14} \mathrm{C}\right.$ dates $)$

- loess between the E2-Naßboden and the Eltville tephra: $16,900 \pm 700$ years B.P. (5 TL dates)

- loess between the Eltville tephra and the tongued horizon: $15,500 \pm 700$ years B.P. (5 TL dates)

- loess from the tongued horizon: $15,200 \pm 900$ years B.P. (3 TL dates)

- humus from the tongued horizon: $22,198 \pm 123$ years B.P. $\left(2{ }^{14} \mathrm{C}\right.$ dates $)$

- loess from above the tongued horizon: $13,500 \pm 600$ years B.P. (6 TL dates)

\section{Reliability of absolute ages in the late Weichsel and the Late-glacial}

The reliability of TL dating of recent loess was established using the Laacher See tephra which was deposited during the Aller $\phi$ d Oscillation. A total of sixteen radiocarbon dates have been obtained on charcoal from close to the point of eruption and on organic material immediately adjacent to the ash deposit. These have been listed by BOGAARD \& SCHMINCKE (1985) who conclude that an age between 10,950 and 11,050 years B.P. is most likely for the eruption which resulted in the Laacher See tephra. A sample of loess taken immediately beneath the tephra during excavation of the archaeological site at Niederbieber gave a TL age of $13,000 \pm 1,100$ years B.P. (QTL51B) (WINTLE 1987a). Since no loess younger than the beginning of the Bølling Oscillation (see Fig. 3) is firmly demonstrated in western Europe, the above TL age is totally acceptable. Another age check was made on loess taken immediately beneath a thin charcoal layer at the typesite for the "Stillfried B Soil" in Austria. 


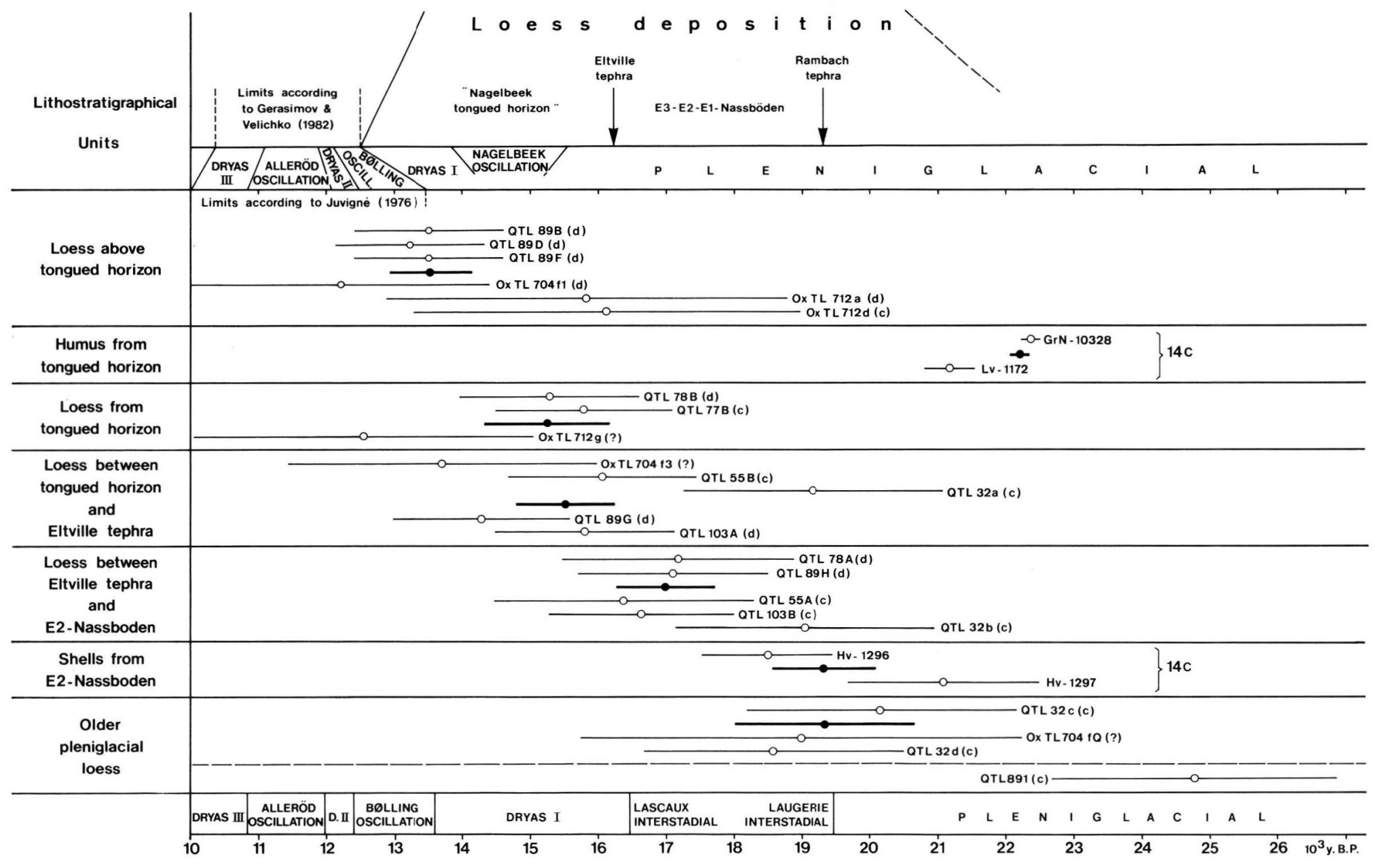


A TL date of $29,800 \pm 2,500$ years B.P. (QTL83C) was obtained (WINTLE 1987a) which is in good agreement with the radiocarbon dates of $28,200 \pm 290 \mathrm{~B}$. P. (GrN-2523), 28,340 \pm 220 B. P. (GrN-2533) and $28,900 \pm 1,400$ B. P. (GrN-11188).

The TL ages presented in figure 3 are self-consistent within the error limits and fit with the radiocarbon ages of the shells from the E2-Naßboden. However, a few absolute ages are contradictory and a chronostratigraphic correlation cannot be made without excluding some of them. The most obvious out-of-line values are the radiocarbon ages on the humus from the tongued horizon. Not only do they not fit with the proposed TL chronology but they also are not consistent with the younger radiocarbon ages obtained for the lower lithostratigraphic unit which contains the E2-Naßboden. Moreover Delibrias (1979) demonstrated that radiocarbon ages using humic material must be rejected as unreliable.

\section{Chronostratigraphic position} of the individual units of the late weichselian loess (Fig. 3)

\section{Oldest pleniglacial loess}

At Rocourt, a sample from the lowest part of the late weichselian loess was dated at $24,800 \pm 2,100$ years B.P. (QTL89I) (Fig. 2 and WINTLE 1987a). This agrees with the time of onset of loess deposition in the second part of the Weichsel in northwestern and central Europe as proposed by HAESAERTS (1985) on the basis of radiocarbon dates on charcoal and archaeological evidence from this region. This sample was taken from a calcareous loess layer which was underlain by a stony layer which separated it from a greyish brown, non-calcareous loess (WINTLE 1987a). This stony layer may correspond to Stoneline E (unit VIIa) described by VREEKEN (1984) for the Brull excavation at Nagelbeek (Limbourg, the Netherlands). At Nagelbeek a radiocarbon date of $26,800 \pm 400$ years B.P. (GrN9014) was obtained for shells from the base of the overlying Middle Silt Loam A (unit VIIb) (VREEKEN 1984). The tongued horizon was located higher in the section at the top of the Middle Silt Loam C (unit VIII). A volcanic ash within unit VIII at Nagelbeek has been reported by MEIJS (1980), JUVIGNÉ \& SEMMEL (1981), MEIJS et al. (1983) and VANDENBERGHE (1985).

In middle Germany the lowest late weichselian loess adjacent to the "Rambacher/Wallertheimer Tuff" (BRUNNACKer \& TILLMANS 1978; SEMmel 1967; ANDRES 1969) were dated by WINTLE \& BRUNNACKER $(1982)$ at $20,200 \pm 2,000$ years B.P. (QTL32C) and $18,600 \pm 1,900$ years B.P. (QTL32D). This provides a mean age of 19,400 years B.P. for the Rambach/ Wallertheim tephra layer which is in agreement with the position of the relevant units within the late Weichsel according to SEMMEL (1969) and ANDRES (1969) but is in disagreement with the interpretation of BRUNNACKER \& TILLMANS (1978).

\section{Eltville tephra layer}

A mean age of about 16,200 years B.P. can be placed on the tephra layer based on the TL ages of the overlying and underlying loess units. Moreover, in each loess profile the tephra layer is interbedded within a typical loess body which shows no sign of soil development, which is consistent with a very arid phase of high loess deposition.

Fig. 3: All available absolute TL and radiocarbon dates obtained on material from the late weichselian loess in this part of middle Europe. Letter between parentheses following designation of sample mean: $d=$ decalcified loess; $c=$ calcified loess;

$?=$ not known. Open circles correspond to individual values and the thin lines to standard deviation $( \pm 1 \sigma)$.

Closed circles represent mean ages for individual units and the thick line is the standard deviation of the mean.

\section{Below: Chronostratigraphy of middle Europe according to JUVIGNE (1976).}

Ordinate: Lithological units. Within each unit the dated samples are not in stratigraphic order. GrN-10328 and Lv-1172 (Gullentops 1981) as well as Hv-1296 and Hv-1297 (SEMMEL 1967) are radiocarbon dates. All the other ages were obtained by TL. OxTL712a, d, and g according to HuXTABLE \& AITKEN (1985). Since the Eltville tephra was not found at MaastrichtBelvédère (VANDENBERGHE et al. 1985) the samples were assigned to two units according to the field notes of the authors. OxTL 704f 1 , f2, and $\mathrm{f} 3$ were from Biache-Saint-Vaast according to AITKEN et al. (1986). QTL 32 A, B, C, and D according to WINTLE \& BRUNNACKer (1982). The ages of loesses adjacent to the Wallertheimer Tuff (QTL32C and D) were placed in the figure according to SEMMEL (1969) and ANDRES (1969). QTL89 B, D, F, G, H, and I according to WINTLE, (1987 a). Within the unit "Older pleniglacial loesses" the mean value was calculated using only the TL ages from Wallertheim because there is no precise correlation with the lowermost late weichselian loess at Rocourt.

The remaining ages were obtained on new samples and are listed in table 1.

Above: New chronostratigraphic divisions based on the late weichselian loess stratigraphy as proposed in the text with the main geological units placed according to their individual absolute ages. For the younger lateglacial oscillations age brackets are shown according to GERASIMOV \& VELICHKO (1982) and JUVIGNE (1976). 


\section{E 1-, E2-, E3-Naßböden}

According to the TL ages, these wet soils developed during the Laugerie-Lascaux interstadial (LEROIGOURHAN 1968). Since the Naßböden are weakly developed soils and the interbedded loess bodies fit with arid phases, it seems that the term interstadial is somewhat excessive to designate the relevant phase that was recorded in western Belgium by BASTIN (1971) using a pollen diagram.

It should be emphasized that neither of the above "interstadials" are recorded in the two continuous pollen records of Grande Pile/France (WOILLARD 1978) and Les Echets/France (BEAULIEU \& REILLE 1984). Moreover the latter authors clearly pointed out that the "Laugerie-Lascaux Interstadial" should be removed from general usage and even LEROIGOURHAN (1986) no longer mentions that interstadial in her most recent stratigraphy of the late Pleistocene.

\section{The tongued horizon}

Since the mean TL age of the tongued horizon, 15,200 years B.P., applies to the deposition of loess and not to the development of soil, the penetration of humus into the loess must have occurred during a more recent temperate phase. On the other hand this temperate phase must be older than the age of the overlying loess body which has a mean TL age of $13,500 \pm 600$ years B.P. It must also be older than the age of the beginning of the "B $\phi$ lling Oscillation" at which time loess deposition stopped in middle Europe. This implies that the relevant age of 12,400 years B.P. (GERASIMOV \& VELICHKO 1982) is more realistic than that of 13,400 years B.P. reported by JUVIGNE (1976). Hence the temperate phase corresponding to the tongued horizon can be placed between about 14,000 and 15,000 years B.P. This warming phase is named the "Nagelbeek Oscillation", referring to the type locality of the tongued horizon. Its introduction splits the Dryas I into two parts. Since there is no sign of soil development between the E3-Naßboden and the tongued horizon, the older part of the previous Dryas I must be integrated into the Pleniglacial as previously suggested by BeAUlieu \& ReILle (1984) on the basis of palynology.

In the tradition of the misuse of the terms, tongued horizon and Kesselt Soil, described earlier, BASTIN (1971) reported an important development of Pinus as well as thermophilous tree pollens within the tongued horizon at Kesselt. The relevant warming phase was correlated to the Midweichselian Interstadial under the name of "Arcy-Kesselt Interstadial". In our opi- nion this pollen suite must be related to the Nagelbeek Oscillation. In their discussion of the continuous record at Les Echets, BeAUlieU \& REILlE (1984) demonstrated that the only major botanical event which occurred after the Midweichselian Interstadial took place at about 15,000 years B.P.

A correlation could also be proposed with the "Angles-sur-l'Anglin Oscillation" (BASTIN 1975) that was recorded in a similar stratigraphic position in western Belgium by HAESAERTS \& BASTIN (1977).

According to VANDENBERGHE (1983), the underlying tonguing could have been formed when a slight warming resulted in liquefaction of sediment on top of frozen ground. If this is so, the tonguing could be synchronous with the phase of supply of humus corresponding to the warming of the "Nagelbeek Oscillation".

A similar humic loam has been described by HAEST et al. (1986) underneath coversands at Beerse-Dam in northern Belgium. The pollen record is dominated by Pinus, as found at Kesselt by BASTIN (1971). However, a radiocarbon date of $16,950 \pm 170$ years B.P. (GrN12286) was obtained on humic acids extracted from $5 \mathrm{~kg}$ of humic loam. This age was dismissed by the authors as being too young compared with the tongued horizon and they suggested that it had been contaminated by $5 \%$ of modern humic acids. This demonstrates once more the unreliability of radiocarbon ages on humic matter.

\section{Loess sheet overlying the tongued horizon}

We agree with the generally held view that loess deposition stopped in middle Europe at the beginning of the $\mathrm{B} \phi$ lling Interstadial. Hence the uppermost loess was deposited between about 14,000 and 12,400 years B. P. We consider an age of 12,400 years B.P. for the beginning of the $B \phi$ lling to be more realistic than that of 13,400 years B.P. reported by JUVIGNE (1976). Because the loess sheet is about 3 meters thick on the plateaux, the loess deposition rate must have been about $2 \mathrm{~mm} /$ year. This is in agreement with values accepted by MUCHER (1986) for sedimentation of loess in middle Europe.

Large ice wedge casts originating in this loess and penetrating the tongued horizon and the Eltville tephra have been recorded at Nagelbeek (VANDEN. BERGHE 1985) as well as at Rocourt and Kesselt (HAESAERTS et al. 1981). These are most likely to have formed during a period of continuous permafrost and some may have formed as late as Dryas I (HAESAERTS 1974). 


\section{Discussion}

\subsection{Comparison with loesses having TL ages in other parts of western Europe}

A set of recent ages ranging from 11,100 to 16,400 years B.P. (QTL20A-F) has been obtained for the uppermost loess body at Saint Romain in northern France (WINTLE et al. 1984). They were not discussed in the framework of the loess stratigraphy but should now be reassessed in the light of the new chronostratigraphy introduced in this paper. A pure loess from Pegwell Bay, Kent, England, was dated to 14,800 $\pm 3,000$ years B.P. in the first TL dating study on European loess (WINTLE 1981).

\subsection{Effect of decalcification on TL dates}

In an earlier study (WINTLE 1987a) it was suggested that decalcification of the loess might be responsible for the apparent underestimate of the TL ages at Rocourt when they were compared with the two radiocarbon dates at Lixhe and Kesselt. However, samples QTL 103A and B were taken from a new face at Rocourt, where decalcification had only reached down as far as the Eltville tephra. QTL103B underlies the tephra and is highly calcareous. Its age of 16,600 $\pm 1,300$ years $B$. $P$. is in excellent agreement with that of sample QTL $89 \mathrm{H}, 17,100 \pm 1,400$ years B.P. which had experienced decalcification. The presence $(C)$ or absence (D) of calcium carbonate on the TL ages is shown on the right hand side of figure 3 and no systematic difference can be observed in the TL dates.

\section{Conclusion}

Using a self-consistent set of $\mathrm{TL}$ and ${ }^{14} \mathrm{C}$ ages for material from loess sections in middle Europe, a new chronostratigraphy for the late weichselian loess is proposed.

The tongued horizon is confirmed as the most important morphostratigraphic horizon of the late Weichsel. The humus contained in it probably developed between about 15,000 and 14,000 years B.P. The relevant warming period is named the "Nagelbeek Oscillation". Its introduction shortens the Dryas I.

In the late weichselian loess there is no sign of interstadial climate during the Laugerie-Lascaux Interstadial that could be represented by three phases of wet soil development which alternate with arid phases; in this case the term interstadial is somewhat excessive.

A remnant of an earlier late weichselian loess dating from $24,800 \pm 2,100$ years B.P. (QTL 89I) was found at one section at Rocourt, in agreement with accepted theories of loess deposition based on more secure radiocarbon dates on in situ charcoal (HAESAERTS 1985).

Based on the age of adjacent loess bodies, the Eltville tephra can be dated at about 16,200 years B.P. and the Rambach/Wallertheim tephra at about 19,400 years B.P.

Decalcification does not have any effect on the TL ages.

\section{Acknowledgments}

We are indebted to Professor A. PISSART for a critical review of the manuscript and to Dr. N. J. SHACKLETON for useful discussions. The TL laboratory in Cambridge is supported by NERC grant GR 3/3174 and EEC contract no. ST 2 P-0204-1-UK (EDB). Laboratory assistance from C. SOLANKI and S. PACKMAN is gratefully acknowledged.

\section{References}

Aitken, M. J., Huxtable, J. \& Debenham, N. C. (1986): Thermoluminescence dating in the Paleolithic: burned flint, stalagmitic calcite and sediment. - Special Supplement to Bull. Ass. Fr. Et. Quat.: 7-14; Paris.

ANDRES, W. (1969): Über vulkanisches Material unterschiedlichen Alters im Loess Rheinhessens. - Mainzer Naturw. Arch., 8: 134-139; Mainz.

Bastin, B. (1971): Recherches sur l'évolution du Peuplement végétal en Belgique durant la glaciation de Würm. - Acta Geographica Lovaniensia, 9: 136p; Leuven.

Beaulieu De, J. L. \& Reille, M. (1984): A long Upper Pleistocene Pollen record from Les Echets, near Lyon, France. - Boreas, 13: 111-132; Paris.

Berger, G. W. (1986): Dating Quaternary deposits by luminescence-recent advances. - Geoscience Canada, 13: 15-21; Toronto.

BogaARd, v. D., P. \& SChmincke, H. U. (1985): Laacher See Tephra: A widespread isochronous late Quaternary tephra layer in central and northern Europe. - Geol. Soc. Am. Bull., 96: 1554-1571; Boulder/Co.

BiBUS, E. (1973): Ausbildung und Lagerungsverhältnisse quartärer Tuffvorkommen in der Wetterau. - Notizbl. hess. L.-Amt Bodenforsch., 101: 346-361; Wiesbaden.

- (1980): Zur Relief-, Boden- und Sedimententwicklung am unteren Mittelrhein. - Frankfurter geow. Arb., D, 1, 296p.; Frankfurt a. M.

- \& Semmel, A. (1977): Stratigraphische Leithorizonte im Würmloß des Mittelrheingebietes. - Geol. Jb. Hessen, 105: 141-147; Wiesbaden. 
Brunnacker, K., BoenigK, W., Hahn, J. \& Tilmanns, W. (1978): Das Jungpleistozän-Profil von Lommersum/ Niederrheinische Bucht. - Decheniana, 131: 274-286; Bonn.

- \& Tilmanns, W. (1978): Die vulkanischen Tuffe im Loess-Profil von Wallertheim/Rheinhessen. - Geol. Jb. Hessen, 106: 225-259; Wiesbaden.

Delibrias, G. (1979): Problèmes liés à la datation des sols fossiles par le carbonne 14. Bull. Ass. Fr. Et. Quat., 1: 35-42; Paris.

Gerasimov, I. \& VelichKo, A. (1982): Paleogeography of Europe during the last one hundred thousand years. Academy of Sciences of the USSR. Institut of Geography: 156 p.; Moscow.

Gullentops, F. (1954): Contribution à la chronologie du Pléistocène et des formes du relief en Belgique. Mémoires de l'Inst. géol. de l'Université de Louvain, 18: 125-252; Leuven.

- (1980): Lixhe-Grube C. B. R. Führer zur Exkursion der deutschen Quartärvereinigung vom 14. bis 16.09.80, 2: 56-58; Köln.

- (1981): About the climate of the last glaciation in NW Europe. - Preprint of conference of $2 \mathrm{nd}$ June 1981 in Symposium on Quaternary Climatic Variations. Université Catholique de Louvain; Louvain-la-Neuve.

Hafsaerts, P. (1974): Séquence Paléoclimatique du Pléistocene supérieur du bassin de la Haine. - Ann. Soc. Géol. Belg., 97: 105-137; Liège.

- (1985): Les loess du Pléistocène supérieur en Belgique; comparaisons avec les séquences d'Europe Centrale. - Bull. Ass. Fr. Et. Quat., 22-23: 105-115; Paris.

- \& BASTIN, B. (1977): Chronostratigraphie de la fin de 1 a dernière glaciation, à la lumière des résultats de l'étude lithostratigraphique et palynologique du site de Maisière-Canal (Belgique). — Geobios, 10: 123-127; Lyon.

-, Juvigné, E., KuYl, O., Mucher, H. \& Roebroeks, W. (1981): Compte rendu de l'excursion du 13 juin 1981, en Hesbaye et au Limbourg néerlandais, consacrée à la chronostratigraphie des loess du Pléistocène supérieur. - Ann. Soc. Géol. Belg., 104: 223-240; Liège.

Haest, R., Munaut, A., Huysmans, L., Gullentops, F. \& MooK, W. (1986): La stratigraphie de Beerse-Dam (Belgique). - Bull. Ass. Fr. Et. Quat., 25-26: 158-167; Paris.

Huxtable, J. \& Aitken, M. J. (1985): Thermoluminescence dating results for the Paleolithic site Maastricht-Belvédère. - Mededelingen Rijks Geologische Dienst, 39: 41-44; s'Gravenhague.

Juvigné, E. (1976): La Stratigraphie du Quaternaire. In: Géomorphologie de la Belgique. - Hommage au Professeur P. MACAR, A. PISSART, Editeur: 169-179; Liège. Laboratoire de Géographie Physique, Université de Liège.
Juvigné \& Semmel, A. (1981): Un tuf semblable à l'Eltviller Tuff dans les loess de Hesbaye (Belgique) et du Limbourg néerlandais. - Eiszeitalter u. Gegenwart, 31: 83-90; Hannover.

LAutridou, J. P. (1968): Les loess de Saint-Romain et de Mesnil-Esnard (Pays de Caux). - Centre de Géomorphologie du C.N.R.S. Bull., 2: 55 p.; Caen.

Lerol-Gourhan, A. (1968): Dénomination des oscillations würmiennes. - Bull. Ass. Fr. Et. Quat., 17: 218-228; Paris.

- (1986): Notes sur des termes employés pour la chronologie du Pléistocène supérieur. - Bull. Ass. Fr. Et. Quat., 25-26: 182-184; Paris.

LOHR, H. \& BRUNNACKER, K. (1974): Metternicher und Eltviller Tuff-horizont im Würm-Löß am Mittel- und Niederrhein. - Notizbl. hess. L.-Amt Bodenforsch., 102: 168-190; Wiesbaden.

LONG, A. \& RipPeTEAU, B. (1974): Testing contemporaneity and averagin 9 radiocarbon dates. - American Antiquity, 39: 205-215; Menasha.

Meijs, E. (1980): A short note on the Presence of the Eltviller Tuff in the surroundings of Maastricht. - Geologie en Mijnbouw, 59: 409-410; Dordrecht.

-, Mucher, H., Ouwerkerk, G., Romein, A. \& StoltenBERG, H. (1983): Evidence of the presence of the Eltville Tuff layer in Dutch and Belgian Limbourg and the consequences for the loess stratigraphy. - Eiszeitalter $u$. Gegenwart, 33: 59-78; Hannover.

MuCHer, H. (1986): Aspects of Loess and loess-derived Slope Deposits: an Experimental and Micromorphological Approach. - Nederlandse Geografische Studies 23. Koninklijk Nederlands Aardrijkskundig Genootschap. Fysisch Geografisch en Bodemkundig Laboratorium Universiteit van Amsterdam: 267 p.; Amsterdam.

PAEPE, R. (1966): Comparative stratigraphy of Würm loess deposits in Belgium and Austria. - Bull. Soc. belge Géol., 75: 203-216; Bruxelles.

- \& Somme, J. (1970): Les loess et la stratigraphie du Pléistocène récent dans le Nord de la France et en Belgique. - Ann. Soc. Géol. du Nord, 40: 191-201; Lille.

ROHDENBURG, H. (1966): Eiskeilhorizonte in südniedersächsischen und nordhessischen Lößprofilen. - Mitt. dt. Bodenkundl. Ges., 5: 137-170; Göttingen.

— \& MEYER, B. (1966): Zur Feinstratigraphie und Paläopedologie des Jungpleistozäns nach Untersuchungen an südniedersächsischen und nordhessischen Lößprofilen. - Mitt. dt. Bodenkundl. Ges., 5: 1-135; Göttingen.

- \& Semmel, A. (1971): Bemerkungen zur Stratigraphie des Würm-Lößes im westlichen Mitteleuropa. Notizbl. hess. L.-Amt Bodenforsch., 99: 246-252; Wiesbaden. 
SCHÖNHALS, E. (1951): Über fossile Böden in nicht vereisten Gebieten. Eiszeitalter u. Gegenwart, 1: 109-130; Öhringen/Württ.

- (1959): Der Basalt-Tuff von Kärlich als Leithorizont des Würm-Hochglazials. - Fortsch. Geol. Rheinld. u. Westf., 4: 313-322; Krefeld.

-, Rohdenburg, H. \& Semmel, A. (1964): Ergebnisse neuerer Untersuchungen zur Würmlöß-Gliederung in Hessen. - Eiszeitalter u. Gegenwart, 15: 199-206; Öhringen/Württ.

Semmel, A. (1967): Neue Fundstellen von vulkanischem Material in hessischen Lößen. - Notizbl. hess. L.-Amt Bodenforsch., 95: 104-108; Wiesbaden.

- (1974): Der Stand der Eiszeitforschung im Rhein-MainGebiet. - Rhein-Main. Forsch., 78: 9-56; Frankfurt a. M.

Somme, J. (1978): Le gisement paléolithique de BiacheSaint-Vaast (Pas-de-Calais). — Bull. Ass. Fr. Et. Quat., 54: 27-67; Paris.

VAndenberghe, J. (1983): Some periglacial phenomena and their stratigraphical position in weichselian deposits. - Polarforschung, 53: 97-107; Goslar.

- (1985): Solution slots or ice-wedge casts? - Mededelingen Rijks Geologische Dienst, 39: 35-39; s'Gravenhague.

—, Mucher, H. J., Roebroeks, W. \& Gemke, D. (1985): Lithostratigraphy and Paleoenvironment of the Pleistocene deposits at Maastricht-Belvédère, Southern Limburg, The Netherlands. - Mededelinge Rijks Geologische Dienst, 39: 7-18; s'Gravenhague.
VREECKEN, W. (1984): (Re)deposition of loess in southern Limbourg, The Netherlands. 3. Field evidence for conditions of deposition of the Middle and Upper Silt Loam complexes, and landscape evolution at Nagelbeek. Earth Surface Processes and Landforms, 9: 1-18; Chichester

WintLe, A. G. (1981): Thermoluminescence dating of late Devensian loesses in southern England. - Nature, 289: 479-480; London.

- (1987a): Thermoluminescence dating of loess at Rocourt, Belgium. - Geologie en Mijnbouw, 66: 35-42; s'Gravenhague.

- (1987b): Thermoluminescence dating of loess. Catena, Supplement, 9: 103-115; Braunschweig.

- \& BRUNNACKER, K. (1982): Ages of volcanic tuff in Rheinhessen obtained by thermoluminescence dating of loess. - Die Naturwissenschaften, 69: 181-182; Stuttgart.

— \& Huntley, D. J. (1982): Thermoluminescence dating of sediments. - Quaternary Science Reviews, 1: 31-53; Oxford.

—, Shackleton, N. J. \& Lautridou, J. P. (1984): Thermoluminescence dating of periods of loess deposition and soil formation in Normandy. - Nature, 310: 491-493; London.

Wolllard, G. M. (1978): Grande Pile Peat Bog: A Continuous Pollen Record for the Last 140,000 Years. Quaternary Research, 9: 1-21; New York.

Manuscript accepted on 18. 5. 1987. 